\title{
Land Suitability Evaluation for Rice Field: Farmers' Effort to Decrease Land Limitation in Mekarsari, South Kalimantan
}

\author{
Deasy Arisanty \\ Geography Education Department, \\ Faculty of Teaching and Education, \\ Universitas Lambung Mangkurat, \\ Banjarmasin, Indonesia \\ deasyarisanty@unlam.ac.id
}

\author{
Sidharta Adyatma, Ellyn Normelani \\ Geography Education Department, \\ Faculty of Teaching and Education Science, \\ Banjarmasin, Indonesia \\ Universitas Lambung Mangkurat
}

\begin{abstract}
Land in Mekarsari Sub Dictrict could be classified as the swampy land. Swampy land was used as the rice field. The objectives of research was to evaluate the land suitability for rice field, and to analyze the farmers effort to overcome land limitation in Mekarsari Sub-district. Land unit map was used as the sampling location of research. Number of land unit was 36 unit. Land unit was earned from map overlay, i.e. landform map, landuse map, slope map, and soil map. The result of research showed that Mekarsari area was classified as suitable (S2), with the area was $143.50 \mathrm{Km}^{2}$. The limitation factor of land suitablity was temperature, cation exchange capacity, and drainage. The farmers efforts to decrease the land limitation were using the Banjar system, such as preparing the seed in early wet season, and using the fertilizer to increase the cation exchange capacity.
\end{abstract}

Keywords - land, suitability, rice field, farmers effort

\section{INTRODUCTION}

Land evaluation is the early processes to produce the data and information of land resources. The land resources data and information uses to determine the policy of agriculture development. Land potency to develop the comodity is one of effort to get the high quality of agriculture product. The assement of land potency can be used to revise the agricultural system [1]. Land evaluation is one of method to determine land potention based on criteria of land suitability classification [2].

Land is used to meet the needs such as food, clothing and agricultural development efforts, livestock and plantations related to the land. Land is the series of attributes in earth surface, such as soil, water, plant, et.al [3].

Land use has the high relation to land utilization and land evaluation. Land utilization is related to present or current land use due to the dynamic of human activity in earth surface. Land utilization is not only related to agriculture activity but also related to industry, and services [4].

Land evaluation assess the land for specific purpose. Land evaluation activity consists of implementation, survey interpretation, and study of landform, soil, vegetation, climate, and another land aspect [5].

Barito Kuala District has the low plain. The topography of Barito Kuala is $0.2-3 \mathrm{~m}$ below sea level. The condition of Barito Kuala causes the area as the centre of rice production in Kalimantan Selatan Province [6].

Mekarsari Sub-district is one of Sub-district in Barito Kuala. Mekarsari has 9 villages. The area of Mekarsari is about 13,350 Hectare. The area is dominated by tidal land. The tidal land is used as the rice field. Total of rice field in Mekarsari is about 7,867 Hectare [6].

Mekarsari becomes the centre of tidal rice field due to the high potention of tidal land. The objectives of research are to evaluate the land suitability for rice field, and to analyze the farmers effort to overcome land limitation in Mekarsari Subdistrict.

\section{METHOD}

Land unit map is used as the sample area. Land unit map is obtained from landform map, slope map, soil map and landuse map. The research area has 36 land unit. Land unit map is presented in Fig 1.

Primary data is collected based on land unit map. Primary data consists of rooting medium, nutrient retention, and terrain. Secondary data consists of temperture and rain fall.

Land suitability evaluation uses matching method. Matching method compares between suitability criteria and field land data and laboratory data. Land quality and characteristic classification is presented in Table 1 [2]. Matching method uses the limitation factor. Land suitability classification for rice [7] follows:

1. S1 (very suitable): Land unit has less than one small limitation.

2. S2 (suitable): Land unit has more than one of small land limitation or one of medium limitation.

3. S3 (slightly suitable): Land unit has more than medium limitation or one of heavy limitation.

4. N1 (not suitable temporarily): Land units have two or more heavy limits that can still be repaired.

5. N2 (not suitable permanently): Units of land have an 
irreparable weight restriction

To understand the farmers effort to decrease the land limitation uses the result of previous research [8]. The result of previous research is related to the farmers activity in tidal rice field.

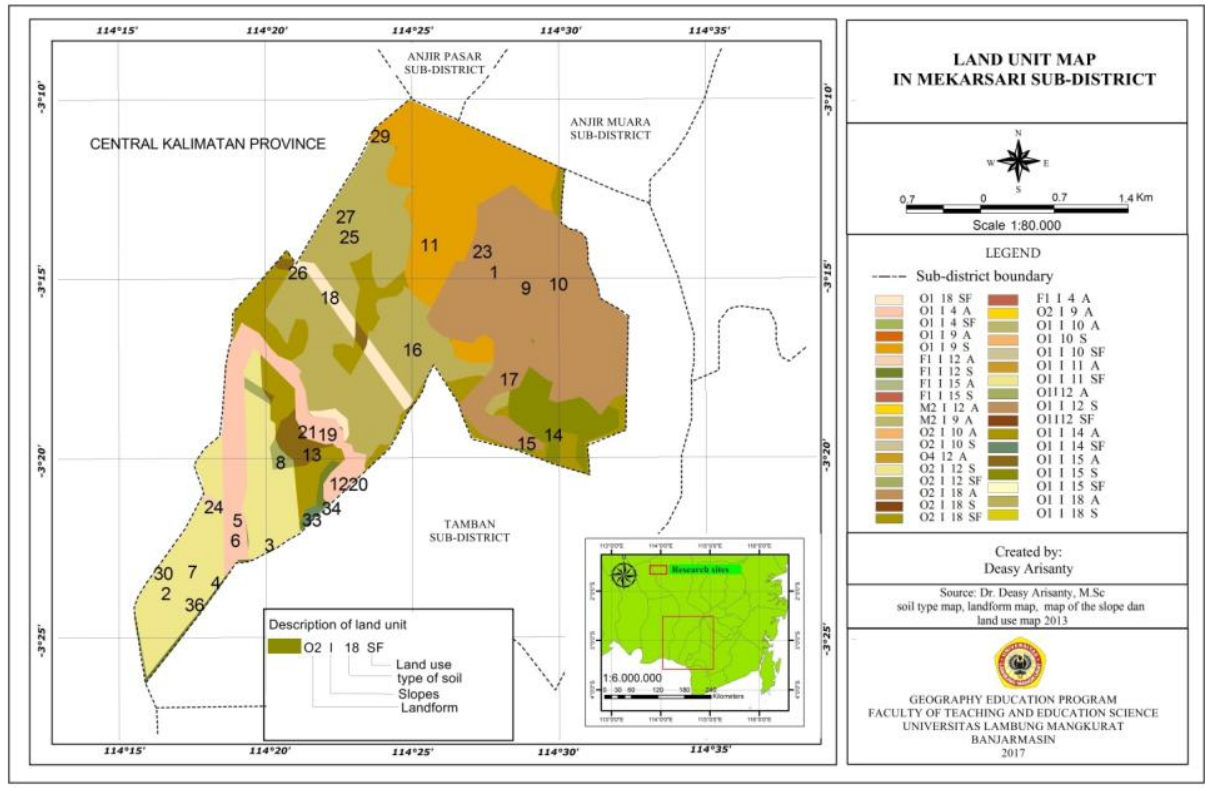

Fig 1. Land Unit Map of Mekarsari Subdistrict

TABLE 1. LAND QUALITY AND CHARACTERISTIC FOR PADDY SUITABILITY

\begin{tabular}{|c|c|c|c|c|c|c|}
\hline \multirow[t]{2}{*}{ No. } & \multirow{2}{*}{$\begin{array}{c}\text { Land Quality/ Land } \\
\text { Characteristic }\end{array}$} & \multicolumn{5}{|c|}{ Land Suitability Class } \\
\hline & & S1 & S2 & S3 & N1 & $\mathrm{N} 2$ \\
\hline 1 & $\begin{array}{l}\text { Temperature }(\mathrm{t}) \\
\text {-average }\left({ }^{0} \mathrm{C}\right)\end{array}$ & $24-29$ & $\begin{array}{l}>29-32 \\
22-<24\end{array}$ & $\begin{array}{c}>32-35 \\
<22\end{array}$ & $\begin{array}{c}35-40 \\
<18\end{array}$ & $>40$ \\
\hline 2 & $\begin{array}{l}\text { Water Available } \\
\text {-Dry month } \\
\text {-rainfall }(\mathrm{mm})\end{array}$ & $\begin{array}{c}<3 \\
>1500\end{array}$ & $\begin{array}{c}3-<9 \\
1200-1500\end{array}$ & $\begin{array}{c}9-9.5 \\
800\end{array}$ & $\begin{array}{l}- \\
-\end{array}$ & $\begin{array}{l}>9.5 \\
<800\end{array}$ \\
\hline 3 & $\begin{array}{l}\text { Rooting Medium (r) } \\
\text {-Soil drainage } \\
\text {-Soil texture } \\
\text {-Soil depth }\end{array}$ & $\begin{array}{c}\text { Good } \\
\text { SCL, Sil, Si, Cl } \\
>50\end{array}$ & $\begin{array}{c}\text { Hampered } \\
\text { SL, L, SiCL, C, } \\
\text { SiC } \\
40-50\end{array}$ & $\begin{array}{l}\text { Medium } \\
\text { LS } \\
\leq 25\end{array}$ & $\begin{array}{c}\text { Rather quickly } \\
\text { Sand } \\
20-10\end{array}$ & $\begin{array}{l}\text { Quickly } \\
\text { Pebble } \\
<10\end{array}$ \\
\hline 4 & $\begin{array}{c}\text { Nutrient Retention (f) } \\
\text {-Cation exchange } \\
\text { - } \mathrm{pH}\end{array}$ & $\begin{array}{l}\text { Medium } \\
5.5-8.0\end{array}$ & $\begin{aligned} & \text { Low } \\
&> 7.0-8.0 \\
& 4.5-5.5\end{aligned}$ & $\begin{array}{c}\text { Very low } \\
>8.8 \\
<4.75\end{array}$ & $\begin{array}{c}\text { Very low } \\
8.5 \\
4.0\end{array}$ & - \\
\hline 5 & $\begin{array}{c}\text { Terrain/Potention/ } \\
\text { Mechanization (s/m) } \\
\text {-Slope }(\%) \\
\text {-Surface rock }(\%) \\
\text {-Rock outcrop }(\%)\end{array}$ & $\begin{array}{l}<3 \\
<3 \\
<2\end{array}$ & $\begin{array}{l}3 \\
2 \\
2\end{array}$ & $\begin{array}{l}>8 \\
>15 \\
>10\end{array}$ & $\begin{array}{l}>15 \\
- \\
>25\end{array}$ & $\begin{array}{l}>25 \\
>40 \\
>40\end{array}$ \\
\hline
\end{tabular}

\section{RESULT AND DISCUSSION}

\section{A. Land Characteristic}

\section{1) Landform}

Landform in Mekarsari presented in Table 2.

TABLE 2. LANDFORM IN MEKARSARI

TABLE 2. LANDFORM IN MEKARSARI
\begin{tabular}{|c|c|l|r|}
\hline No & Symbol & \multicolumn{1}{|c|}{ Landform } & Area $\left(\mathrm{km}^{2}\right)$ \\
\hline 1 & O1 & $\begin{array}{l}\text { Basin of peat anticline, material pebble, } \\
\text { sand, clay and mud }\end{array}$ & 120.50 \\
\hline
\end{tabular}

TABLE 2. cont.

\begin{tabular}{|c|c|c|r|}
\hline 2 & O2 & $\begin{array}{l}\text { Limb of peat anticline, material pebble, } \\
\text { sand, clay and mud }\end{array}$ & 10.44 \\
\hline 3 & F1 & $\begin{array}{c}\text { Natural levee, material pebble, sand, } \\
\text { silt, clay and mud }\end{array}$ & 7.80 \\
\hline 4 & M2 & $\begin{array}{l}\text { Tidal flat, material pebble, sand, silt, } \\
\text { clay and mud }\end{array}$ & 4.76 \\
\hline \multicolumn{2}{|c|}{ Total Area } & 143.50 \\
\hline
\end{tabular}

Genesis of landform in Mekarsari is organic processes landform, fluvial processes landform and marine processes 
landform. Organic processes landform consists of basin of peat anticline, material pebble, sand, clay and mud (O1), and limb of peat anticline, material pebble, sand, clay and mud (O2) that the area of both landform are about $120.50 \mathrm{~km}^{2}$ and $10.44 \mathrm{~km}^{2}$. Area of marine landform (M2) is about $4.76 \mathrm{~km}^{2}$. Area of fluvial landform (F1) is about $7.80 \mathrm{~km}^{2}$.

Basin of peat anticline and limb of peat anticline landforms are formed by the sedimentation of dead plants, that landform is formed of peat soil. The region is a peat dome. The process of peat development causes a decline in the area of peat dome into a basin.

Fluvial landform is formed by river processes. Natural levee is formed by sedimentation processes of river. Marine landform is formed on seawater, i.e. wave and tides. Tides processes was formed tidal flat, material consists of pebble, sand, silt, clay and mud [9].
2) Soil

Soil texture in Mekarsari is presented in Table 3. TABLE 3. SOIL TEXTURE IN MEKARSARI

\begin{tabular}{|c|l|}
\hline Landform & \multicolumn{1}{|c|}{ Soil Texture } \\
\hline O1 & Clay, silty clay, silty clay loam \\
\hline O2 & Silty clay, clay \\
\hline F1 & Clay, silty clay, silt loam \\
\hline M2 & Silty clay, clay \\
\hline
\end{tabular}

Soil in Mekarsari has the fine texture. Soil in Mekarsari is rich of organic matters, hence the area is fertile for agriculture. The area has the mottling, due to reduction and oxidation reaction in soil [9-10].

Some location in Mekarsari is peat soil. Peat soil has the sapric peat soil. The soil has the depth about $50 \mathrm{~cm}-1 \mathrm{~m}$ [9-10].

\begin{tabular}{|c|c|l|c|}
\hline No & Code & \multicolumn{1}{|c|}{ TABLE 4. SOIL IN MEKARSARI } & \multicolumn{1}{|c|}{ Area $\left(\mathrm{km}{ }^{2}\right)$} \\
\hline 1 & 4 & $\begin{array}{l}\text { Hf. h/s Association of ombrogenic hemists and saprists } \\
\text { E eolian sediments } \\
\text { Ed. Coastal sand dunes }\end{array}$ & 33.04 \\
\hline 2 & 9 & Anb.g shallow and massive grey clayey over grey ripe clay & 10.99 \\
\hline 3 & 10 & $\begin{array}{l}\text { Anb.s moderately deep and structured brown clayey over grey ripe clay } \\
\text { Apb. Basin (acid and very potentially very acid) }\end{array}$ & 8.15 \\
\hline 4 & 11 & Apb.b shallow and massive grey clayey over grey unripe clay & 14.49 \\
\hline 5 & 12 & Apb.b moderately deep and massive brown clayey over grey ripe clay & 17.69 \\
\hline 6 & 14 & Asb.g shallow and massive grey clayey over grey ripe clay & 7.13 \\
\hline 7 & 15 & Asb.b moderately deep and massive brown clayey over grey ripe clay & 42.94 \\
\hline 8 & 18 & Fno.s moderately deep and structured brown clayey over grey half ripe clay & Total Area \\
\hline
\end{tabular}

\section{3) Landuse}

Landuse in research is agricuture, swampy forest, and settlement. Agriculture area consists of rice field, and vegetable field. Swampy forest is managed by local community. Swampy forest is changed for rice field and vegetable field. Settlement is located in along of river. Landuse in Mekarsari is presented in Table 5.

TABLE 5. LANDUSE IN MEKARSARI

\begin{tabular}{|l|l|l|r|}
\hline No & Code & Landuse & Area $\left(\mathrm{km}^{2}\right)$ \\
\hline 1 & A & Agriculture & 85.96 \\
\hline 2 & SF & Swampy Forest & 54.87 \\
\hline 3 & S & Settlement & 2.67 \\
\hline & Total area & 143.5 \\
\hline
\end{tabular}

\section{4) Slope}

Slope of Mekarsari is flat (0-3\%). The elevation in area is $0-5 \mathrm{~m}$. Mekarsari is the swamp area, hence the area has the low elevation.

\section{B. Land Suitability for Rice Field Land}

Research area has the rainfall about $1,700 \mathrm{~mm} /$ year. The number of dry month in research area is about 2 month. The climate of research area based on based on Schmidt Ferguson classification is B (wet) with value of Q is 0.255 .

All of land unit of research area is classified as suitable (S2). Land limitation is drainage, temperature and cation exchange capacity. Rice is suitable in swamp area, due to the swamp area has the bad drainage. Cation exchange capacity is related to organic matter available for plant. Cation exchange capacity is the indicator of soil fertility. The area has the good of rooting medium, $\mathrm{pH}$ and mechanization potention.Tidal water flow causes the water change in research area, hence the $\mathrm{pH}$ of water is classified normal.

Community in tidal area has been adapted with the tidal environment. They has been implemented the rice cultivated cycle. Community in Mekarsari uses the Banjar System in preparing of land until paddy haversting [8]. Banjar system in land preparing consist of tajak-puntal-balik-hambur. Seedbed system consists of taradak-ampak-lacak. Arrangement system consists of tongkonan [11]. Agriculture system has the conventional, due to the using the traditional agricultural tools. Varietas local of paddy in research area is planted in once a year.

Land preparing uses the simple tools called tajak. Land is added fertilizer and calc. Function of fertilizer is to repair the cation exchange capacity.

Seedbed is started in wet season. Paddy needs the enough of waters, hence the rainfall is important for paddy growth. Paddy seed is planted in small area, then the seed is planted about 30-40 day. When the seed have begun to grow large, the seed is moved on a wider land. The roots of rice plants have started strong, hence it is intended to adapt to 
swamp environment. People adapt to bad drainage. The existence of such adaptation causes a decrease in the effect of the limitation for the farmers.

\section{CONCLUSION}

Mekarsari has 36 units of land. These land units have characteristics such as landforms of basin of peat anticlinal, limb of peat anticlinal and natural levee, and tidal flat. Chracteristic of land is fine texture of clay and silty clay; flat slope; and agriculture, swampy forest and settlements landuse. Land suitability for rice field in Mekarsari is suitable (S2) with total area of $143.50 \mathrm{~km} 2$. The land boundaries are drainage, temperature and cation exchange capacity. Banjar system is used to decrease the land limitation.

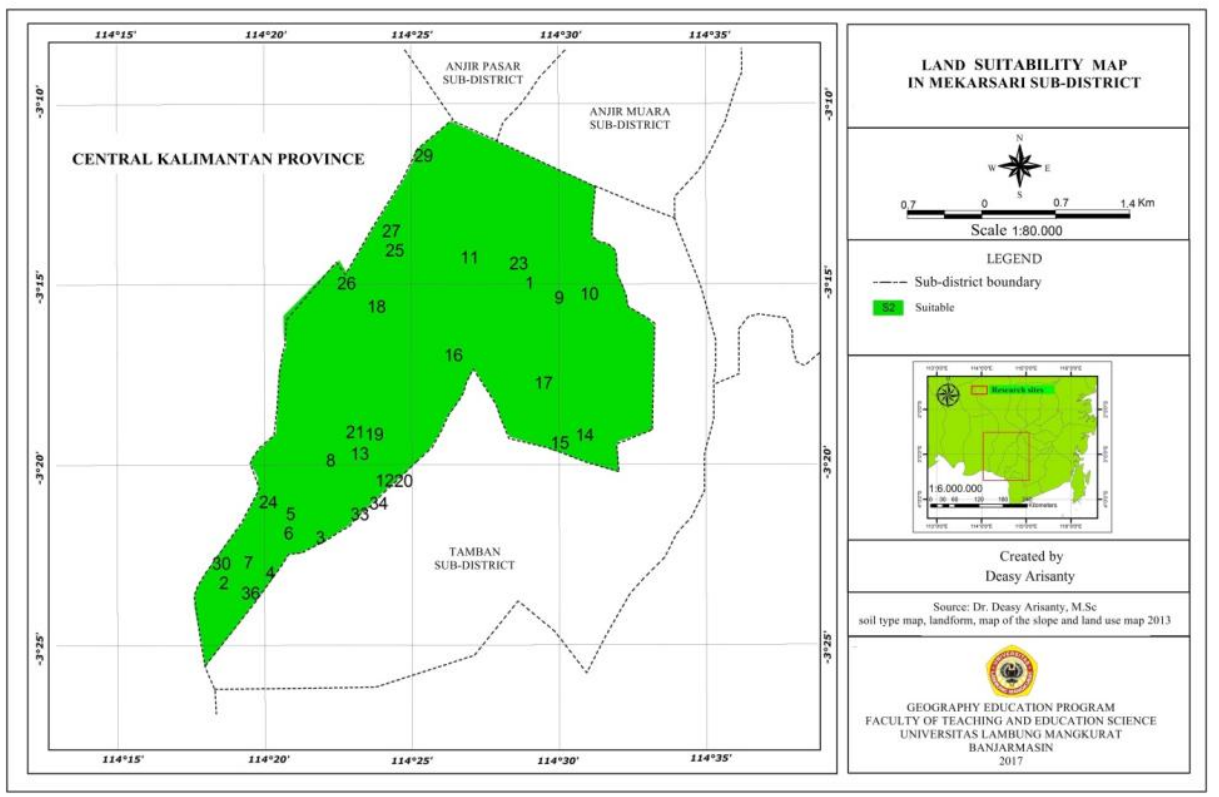

Fig 2. Land Suitability for Rice Field

\section{REFERENCES}

[1] E.D. Waas, and J.B Alfons, "Evaluasi Kesesuaian Lahan Mendukung Usahatani Tanaman Pangan Lahan Kering di Desa Debut Kecamatan Kei Kecil Kabupaten Maluku Tenggara, Provinsi Maluku”, Jurnal Budidaya Pertanian, Vol. 8. No 2, 2012, pp 109-116

[2] S. Ritung, F. Wahyunto, H. Agus, and Hidayat, Panduan Kesesuaian Lahan dengan Contoh Peta Arahan Penggunaan Lahan Kabupaten Aceh Barat. Balai Penelitian Tanah dan World Agroforestry Centre: Bogor, 2007.

[3] B.H. Simanjuntak, "Evaluasi Lahan untuk Budidaya Tanaman", AGRIC Vol 16 no. 1, 2003, pp 1-12

[4] Su, Ritohardoyo, Penggunaan dan Tata Guna Lahan. Yogyakarta: Ombak, 2013.

[5] Z.I. Hayati, "Evaluasi Kemampuan Lahan Beberapa Tempat di Tanjung Pati dengan Menggunakan Metode Deskriptif FAO”, Jurnal Nasional Ekopedon, JNEP, vol. 2, No 1, 2015, pp 038-042.
[6] BPS Kabupaten Barito Kuala. Barito Kuala dalam Angka, 2014 (online), (https://baritokualakab.bps.go.id/Subjek/view /id/53\# subjekViewTab3|accordion-daftar-subjek3 diakses desember 2016).

[7] S. H Widiatmaka, Evaluasi Kesesuaian Lahan \& Perencanaan Tataguna Lahan. Yogyakarta: Gadjah Mada University Press, 2007

[8] D. Arisanty, Pemanfaatan Delta Barito sebagai Lahan Pertanian Rawa Potensial dengan Sistem Banjar. Prosiding Seminar Nasional Pengelolaan Pesisir dan Daerah Aliran Sungai ke 2, 2016.

[9] D. Arisanty, Morphodynamic of Barito Delta, Southern Kalimantan. Dissertation. Faculty of Geography, Yogyakarta: Universitas Gadjah Mada, 2013

[10] D. Arisanty, "Karakteristik Tanah Gambut di Delta Barito, Kalimantan”, Jurnal Geografi, Vol. 3 No 1, 2014.

[11] M. Noor, and A. Jumberi, Kearifan Budaya Lokal dalam Perspektif Pengembangan Pertanian di Lahan Rawa. Banjarmasin: Balai Penelitian Pertanian Lahan Rawa, 2008. 